\title{
The Diagnosis and Treatment of Craniopharyngioma
}

\author{
Hermann L. Müller \\ Department of Pediatrics and Pediatric Hematology/Oncology, University Children's Hospital, Klinikum Oldenburg \\ AöR, Oldenburg, Germany
}

\author{
Keywords \\ Craniopharyngioma · Hypothalamus · Pituitary · \\ Neurosurgery · Irradiation
}

\begin{abstract}
Craniopharyngioma (CP) is a rare embryonic malformation of the sellar/parasellar region with a low histological grade. Clinical manifestations are related to hypothalamic/pituitary deficiencies, visual impairment, and increased intracranial pressure. Recent insight into the molecular pathogenesis of $\mathrm{CP}$ opens new perspectives on targeted therapy in papillary CP harboring BRAF-V600E mutations. Further research to elucidate pathogenic mechanisms and hopefully prevent hypothalamic involvement of CP is warranted. If the tumor is favorably localized, the therapy of choice is complete resection, with care taken to preserve the optical and hypothalamic functions. In patients with unfavorable tumor localization (i.e., hypothalamic involvement), the recommended therapy is a limited hypothalamus-sparing surgical strategy followed by local irradiation. Surgical treatment strategies should be based on a multidisciplinary approach involving experienced teams. Centralizing the treatment of CP in experienced "centers of excellence" and multicenter-based networks for reference assessments should be considered to assure a high
\end{abstract}

standard of treatment quality. CP recurrence and progression are frequent. Irradiation has proven effective in reducing recurrences and progression. Proton beam therapy, available in a wider range in the near future, will help to avoid radiooncological side effects. Anatomical involvement and/or surgical lesions of posterior hypothalamic areas can result in serious sequelae that compromise quality of life (QoL), such as hypothalamic obesity and psychopathological symptoms. Novel insights into neuropsychological sequelae after CP occurrence should be the basis for the development of therapeutic neuropsychological interventions. CP should be managed as a frequently chronic disease, providing ongoing care of pediatric and adult patients' clinical and QoL consequences by experienced multidisciplinary teams.

(c) 2019 S. Karger AG, Basel

\section{Introduction}

Craniopharyngioma (CP) is a rare embryonic malformation with a low histological grade $\left(\mathrm{WHO} \mathrm{I}^{\circ}\right)$ originating from the remnants of the craniopharyngeal duct in the sellar and parasellar area. Overall survival rates at 20 years after childhood-onset CP are high (87-95\%). However, long-term quality of life (QoL) is frequently impaired due karger@karger.com

(C) 2019 S. Karger AG, Basel

www.karger.com/nen

Karger!
Hermann L. Müller, MD

Department of Pediatrics and Pediatric Hematology/Oncology

University Children's Hospital, Klinikum Oldenburg AöR

Rahel-Straus-Strasse 10, DE-26133 Oldenburg (Germany)

E-Mail mueller.hermann@ @linikum-oldenburg.de 
Fig. 1. Manifestations before diagnosis of symptomatic craniopharyngioma (sym$\mathrm{CP}$ ) in children and adolescents recruited in the KRANIOPHARYNGEOM 2007 trial between 2007 and 2014. Frequency of occurrence of each manifestation (\%) before diagnosis (black) and frequency of occurrence as the initial manifestation (white). The median time (in months) from the appearance of each initial manifestation until diagnosis is indicated as an insert or above each column. The median time interval between the initial manifestation of disease and CP diagnosis was 5 months (range 0.01-108 months). Reproduced from [19] with permission from Springer.

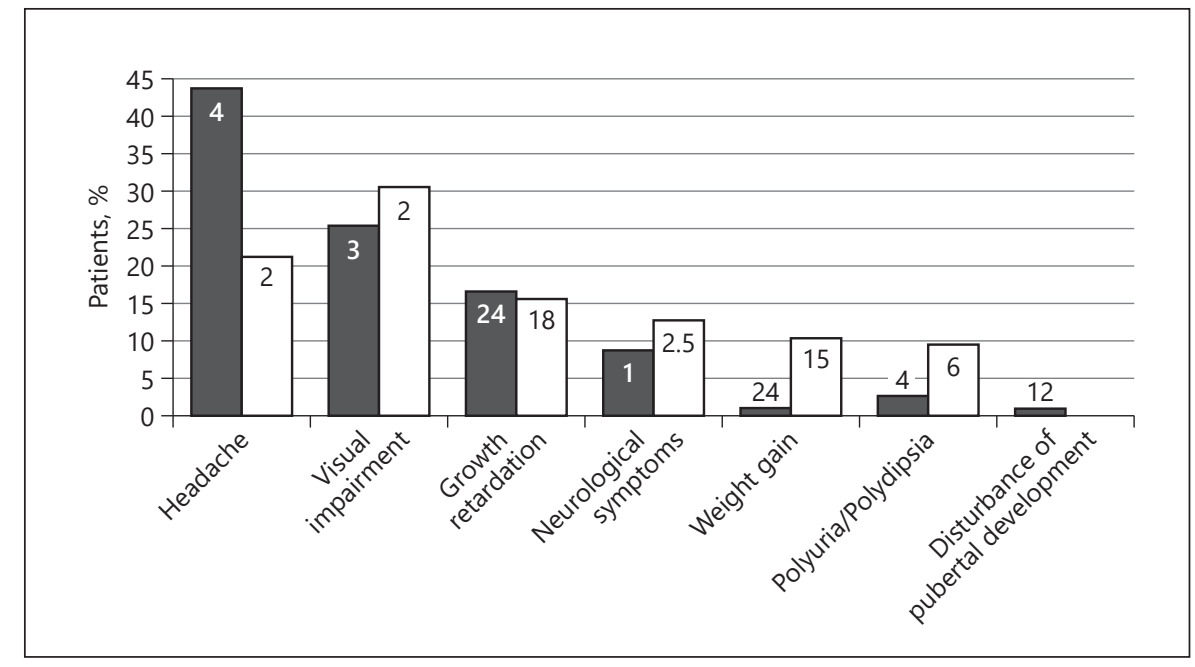

to the sequelae caused by the anatomical proximity of the tumor to the hypothalamic-pituitary axis and optic nerve/ chiasm [1-4]. Initial hypothalamic involvement of CP and/or treatment-related lesions to the hypothalamic-pituitary axis result in hypothalamic obesity (HO). Unfortunately, no generally accepted lifestyle interventions or pharmacological and bariatric therapy for hypothalamic obesity in CP have been proven effective in randomized controlled trials. Currently, the prevention of hypothalamic sequelae is recommended including hypothalamussparing therapeutic approaches that respect the integrity of nuclei located in posterior hypothalamic areas.

\section{Pathology and Molecular Genetics}

Adamantinomatous $\mathrm{CP}(\mathrm{ACP})$ and papillary $\mathrm{CP}(\mathrm{PCP})$ are the $2 \mathrm{CP}$ subtypes. ACP is driven by somatic mutations in CTNNB1 (encoding $\beta$-catenin), mostly point mutations within exon 3 affecting regulatory residues involved in $\beta$-catenin protein stability [5-7]. The consequence of these mutations is that $\beta$-catenin cannot be efficiently degraded, accumulates within the cell, and overactivates the WNT/ $\beta$-catenin pathway $[8,9]$.

PCP, like ACP, also has a low mutational rate $(15 \mathrm{mu}-$ tations/MB), but instead of CTNNB1 mutations, it harbors somatic BRAF-V600E mutations. So far, no other recurrent mutations or genomic aberrations have been identified $[7,10]$. The expression of oncogenic BRAF$V 600 E$ is observed in the vast majority of the tumor cells $[7,11]$. However, the activation of the MAPK pathway is not observed in all tumor cells, as would be expected, but is rather restricted to a few tumor cells (i.e., the basal cells surrounding the fibrovascular cores) [12]. Based on these novel findings in molecular genetics, targeted therapy has provided new promising perspectives for treating PCP haboring BRAF-V600E mutations, exclusively detected in adult-onset PCP [13-16].

\section{Clinical Manifestations}

The diagnosis of childhood-onset CP is often made late, frequently years after the initial manifestation of symptoms [17-19], with a clinical picture characterized by symptoms of increased intracranial pressure (e.g., nausea and headache) at the time of diagnosis (Fig. 1). Further primary manifestations are endocrine deficits (52-87\%) and visual impairments (62-84\%). Endocrine deficiencies are frequently caused by tumor- and/or treatment-related lesions to the hypothalamic-pituitary axis that affect the secretion of growth hormone (GH, 75\%), gonadotropins (LH/FSH, 40\%), thyroid-stimulating hormone (TSH, 25\%), and adrenocorticotropic hormone (ACTH, 25\%). At the time of CP diagnosis, $40-87 \%$ of patients present with at least 1 endocrine deficit [20-22]. Other hormonal symptoms such as neurohormonal diabetes insipidus are observed preoperatively in $17-27 \%$ of all CP patients [21-23]. An analysis of anthropometric data obtained in routine checkups before $\mathrm{CP}$ diagnosis in 90 children [18] revealed reduced growth velocity in infants as young as 12 months. Weight gain, predictive of hypothalamic obesity, occurred as a later manifestation, shortly before CP was diagnosed. Hoffmann et al. [17] 
Fig. 2. BMI and MRI imaging at diagnosis and 36 months after surgery in 3 cases of childhood craniopharyngioma (CP) with different grades of hypothalamic involvement/lesion. a, b Patient with CP confined to the intrasellar space: $0^{\circ}$ no hypothalamic involvement (a)/surgical lesion (b). BMI at diagnosis: -1.96 SD; BMI 36 months after complete resection: -1.62 SD. c, d Patient with $\mathrm{CP}$ involving the anterior hypothalamus: $I^{\circ}$ hypothalamic involvement $(\mathbf{c})$ /surgical lesion of the anterior hypothalamic area (d). BMI at diagnosis: +1.01 SD; BMI 36 months after complete resection: +0.59 S.D. e, f Patient with CP involving the anterior and posterior hypothalamus: $\mathrm{II}^{\circ}$ hypothalamic involvement (e)/surgical lesion of the anterior and posterior hypothalamic area (f). BMI at diagnosis: +6.08 SD; BMI 36 months after complete resection: +6.79 SD. Mammillary bodies define the border between anterior and posterior involvement/lesion. Reproduced from [53] with permission from Bioscientifica.
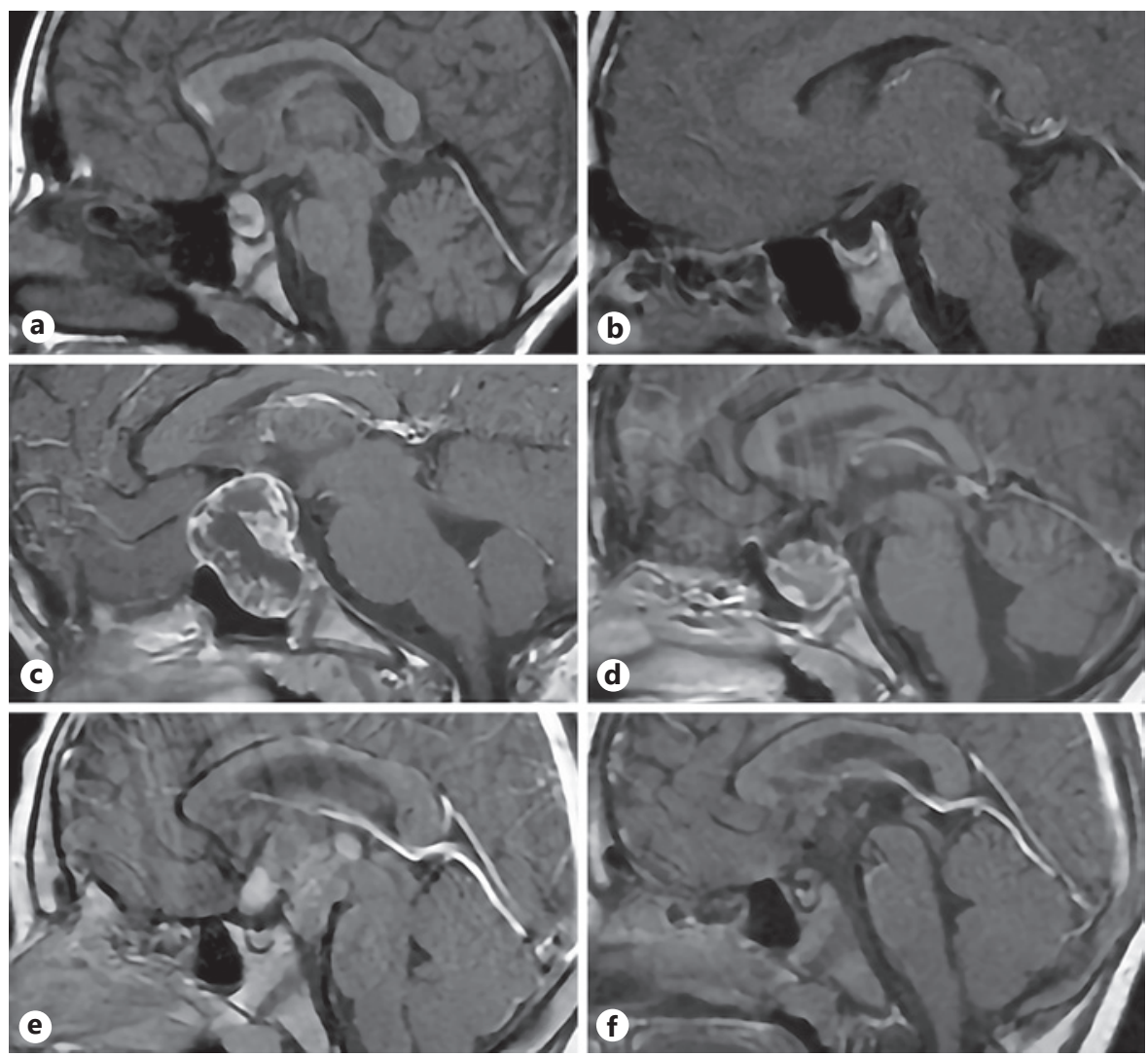

observed that the median duration of history before $\mathrm{CP}$ diagnosis was 6 months, ranging from 0.1 to 108 months, and correlated positively with patient age at diagnosis. Tumor size, degree of surgical resection, hypothalamic involvement, and body mass index (BMI) at diagnosis were not associated with duration of history. Neurological deficits and visual impairment were associated with larger tumor size at diagnosis and reduced the 10-year overall survival rate. Endocrine deficiencies, growth retardation, and weight gain were the symptoms observed with the longest duration of history [17]. A combination of headache, visual impairment, growth retardation, and polyuria/polydypsia is highly indicative of CP and should lead to further neuroradiological diagnostics.

\section{Neuroradiological Imaging}

While PCP is usually a noncalcified and solid entity, the typical combination of imaging features of ACP can be summarized by the so-called $90 \%$ rule, i.e., that about $90 \%$ of tumors are predominantly cystic, $90 \%$ show more or less prominent calcifications, and about $90 \%$ take up contrast in the cyst walls. On MRI before contrast, the solid parts and cyst walls may show a variety of $\mathrm{T} 1$ signals. On T2-weighted images, the tumors are usually hypoand hyperintense [24-27]; this variability is due to the inhomogeneous distribution of calcified parts and the broad individual variation of MR signals in calcifications. Accordingly, the proof of calcifications in CP is usually not possible on MRI. The ideal sequences for the identification of calcifications are T2*-weighted or susceptibility-weighted image (SWI) sequences, both of which are hampered by the air content of the sinuses. Therefore, computed tomography (CT) remains the gold standard for the identification of calcifications in this area, despite the disadvantages of X-ray use in children. The proof of calcifications on imaging is important for the differential diagnosis of other sellar masses and the detection of postoperative small remnants after resection (undetectable on MRI) [24]. The main differential diagnoses of sellar/parasellar masses in children are low-grade glioma and germ cell tumor $[24,28]$. 
For appropriate staging, it is important to assess CP location. A classification by de Vile et al. [29] defined the extent of the postoperative hypothalamic damage as 1 of 3 grades depending on the postoperative defects in the floor of the third ventricle. In German CP studies, a similar classification according to CP contact with or compression of the hypothalamic structures was used. The posterior hypothalamic nuclei are localized in the lateral walls of the third ventricle, beginning at the level of the mammillary bodies and posterior to them. Grade 0 defines a CP without contact to the floor of the third ventricle. Grade I is for a CP with contact or compression of the hypothalamus anterior to the mammillary bodies, and grade II is a tumor that results in dislocation, compression, or destruction of the hypothalamus beginning at the level of the mammillary bodies or dorsal to them (Fig. 2). Routine imaging during follow-up should be confined to MRI without gadolinium application in order to decrease the radiation burden and the potential risk of gadolinium deposition [30].

\section{Neurosurgery}

Surgical management, especially in children, remains controversial. The best treatment for CP is the one that involves the least long-term morbidity. Treatment may include surgery only, irradiation only, or, more commonly, a combination of the two. Surgery alone implies radical resection, and is, therefore, appropriate for tumors that may be completely resected without neurovascular injury and visual impairment. A major factor that affects patients with ACP is hypothalamus dysfunction. In the pediatric population, preoperative hypothalamic involvement (Fig. 1) increases the likelihood of pre- and postoperative obesity, and hypothalamus damage during surgery increases the risk of postoperative weight gain [31-34]. Although not well established, postoperative weight gain in adults is also a problem and correlates with hypothalamic involvement [35]. Accordingly, avoiding irreversible hypothalamic damage is a key goal in the treatment of CP $[1,36]$.

Limited surgery and radiation therapy are appropriate for most patients including those for whom radical surgery might be considered. The concept of limited surgery and radiation therapy involves the use of surgery to alleviate and prevent symptoms, improve a patient's ability to tolerate and complete irradiation, and potentially enhance or optimize dose delivery. Limited surgery comes in many forms including partial resection, cyst fenestra- tion or aspiration, catheter and Ommaya reservoir placement, or cerebrospinal fluid (CSF) diversion. It may be performed to decompress or resect portions of the tumor to reduce its impact on vision, mass effect on the brain or brainstem, reduce its volume for irradiation and dose to critical normal tissue volumes, and restore CSF flow. Like radical surgery, a limited surgery approach depending on the size, location, and extent of the tumor, and the goals of the overall procedure and treatment plan. Additional surgical options may include stereotaxic aspiration, catheter placement, or endoscopic procedures. One should be cautioned that cyst aspiration or fenestration, while important to reduce tumor volume and symptoms, may be of temporary benefit, and the reaccumulation of cyst fluid during irradiation is almost certain. Catheter placement should be considered when justified and feasible.

\section{Radiation Therapy}

Radiation therapy implies external beam radiation therapy using photons or protons [37] (Table 1). In most cases, radiation therapy is administered at the time of progression after prior surgery. The first scenario is where radical resection has been performed and recurrence is unexpected. The second scenario is where attempted radical resection is performed, near-total resection is achieved, and the patient is observed until the time of progression. It is hoped that, in both scenarios, the impact of combined therapies will not be additive, and that additional surgery and its attendant morbidity will not be required prior to definitive irradiation.

$\mathrm{CP}$ is one of the pediatric brain tumors for which proton therapy holds great promise. Conventional radiation therapy uses X-rays directed from multiple directions to conform the prescription dose to the targeted volume at the expense of nontarget tissue, which receives a collateral dose associated with the entrance and exit of the traversing beams. Proton therapy deploys fewer beams that deposit the dose along a path that ends in the target, and the dose to nontarget tissue is significantly reduced. While the potential for tumor control is equal in the two modalities, patients, and their parents and caregivers, prefer the newer modality, hoping that the difference in normal tissue doses will provide an advantage. Regardless of modality, the hypothalamic-pituitary axis, optic nerves, and chiasm, the principle components of cerebral circulation as well as portions of the brainstem receive the prescription dose in most cases. This leaves cognitive effects as one of the few functional outcomes that might be used 
Table 1. Advantages and disadvantages of modern treatment technologies in radiotherapy of craniopharyngioma.

\begin{tabular}{|c|c|c|}
\hline Technology & Advantages & Disadvantages \\
\hline $\begin{array}{l}\text { Conventional 2-dimensional } \\
\text { radiotherapy }\end{array}$ & $\begin{array}{l}\text { reliable clinical data and long-term } \\
\text { follow-up indicating high efficacy }\end{array}$ & $\begin{array}{l}\text { poor geometrical precision; no reliable protection } \\
\text { of normal surrounding tissues }\end{array}$ \\
\hline $\begin{array}{l}\text { Fractionated conformal radiation } \\
\text { therapy/IMRT }\end{array}$ & $\begin{array}{l}\text { widely available; highly conformal; ease } \\
\text { in adapting treatment to changing target }\end{array}$ & $\begin{array}{l}\text { highly conformal photon therapy requires } \\
\text { exposure of a larger volume of normal tissue to } \\
\text { low doses of radiation }\end{array}$ \\
\hline $\begin{array}{l}\text { Hypofractionated image-guided } \\
\text { radiosurgery (CyberKnife) }\end{array}$ & $\begin{array}{l}\text { fewer treatment sessions; highly } \\
\text { conformal; may have biological } \\
\text { advantages under certain conditions }\end{array}$ & $\begin{array}{l}\text { very limited indications and experience; role still } \\
\text { unclear; no reliable data for tumor control or } \\
\text { reuction of side effects }\end{array}$ \\
\hline $\begin{array}{l}\text { Intracavitary colloid isotope } \\
\text { application }\end{array}$ & $\begin{array}{l}\text { high tumor control rates for cystic } \\
\text { components; applicable to tumors } \\
\text { recurrent after prior irradiation }\end{array}$ & $\begin{array}{l}\text { advantages limited to cystic tumors; underdosage } \\
\text { of solid components; complications related to } \\
\text { leakage or high doses when administered in } \\
\text { proximity to vital structures such as visual } \\
\text { pathways and brainstem }\end{array}$ \\
\hline
\end{tabular}

Reproduced from Müller et al. [1] with permission of Springer Nature.

to demonstrate the advantage of proton therapy over photon therapy. In 2011, a prospective study using passively scattered (first-generation) proton therapy was activated. A total of 94 children aged $0-21$ years were enrolled up to early 2016. The targeted volume for proton therapy included the postoperative tumor bed with an added clinical target volume of $0.5 \mathrm{~cm}$ which was meant to account for microscopic tumor extension. Dated from the start of proton therapy, the patients were followed every 3 months for 1 year, and then every 6 months for 5 years. Preliminary reports suggested that the rate and pattern of failure, and the rate of necrosis, vasculopathy, and severe neurological complications associated with the target volume were equivalent to photon therapy [38]. Preliminary results also suggested that when corrected for the distribution of radiation dose in the normal brain, those treated with proton therapy had no change in academic achievement scores (reading and maths) compared to patients treated with photon therapy who demonstrated a significant decline [39]. Since 2016, a newer generation of proton therapy (pencil-beam scanning) has become available. The advantage of this second-generation method over the first generation is the use of small, individually weighted beams to further conform the prescription dose to the target and reduce the volume that receives the highest doses, in addition to the volume that receives the lowest doses.

\section{Instillation of Sclerosing Substances for Cystic CP}

For cystic CP, decompression via an intracystic catheter can be performed repeatedly when connected with an Ommaya reservoir. Mainly for recurrent single cystic CP, intracavitary instillation of sclerosing substances such as interferon- $\alpha$ is a treatment of choice $[40,41]$. Due to neurotoxicity in the case of leakage, bleomycin instillation is obsolete [42]. Systemic interferon alpha treatment has not been proven to be efficient for the prevention of solid CP progression. 
Fig. 3. Weight development in 109 childhood-onset craniopharyngioma (CP) patients, recruited with primary involvement of anterior and posterior hypothalamus in the KRANIOPHARYNGEOM 2007 trial, with regard to surgical hypothalamic lesions (HL) graded as previously described $[28,53]$. No HL; HL of the anterior hypothalamus not involving mammillary bodies and hypothalamic areas dorsal to mammillary bodies; HL of anterior and posterior (Ant + post) hypothalamic areas, involving mammillary bodies and areas dorsal to mammillary bodies. Body mass index (BMI) SDS [107] is shown at the time of diagnosis and at 3 time points after diagnosis ( 1 and 3 years after diagnosis and the last visit). White boxes, BMI SDS at diagnosis; hatched boxes, BMI SDS at 1-year followup; gray boxes, BMI SDS at 3-year followup; black boxes, BMI SDS at the last visit. The horizontal line in the middle of the box depicts the median. The top and bottom edges of the box, respectively, mark the 25 th and 75 th percentiles. Whiskers indicate the range of values that fall within 1.5 box lengths. Reproduced from [36] with permission from Bioscientifica.

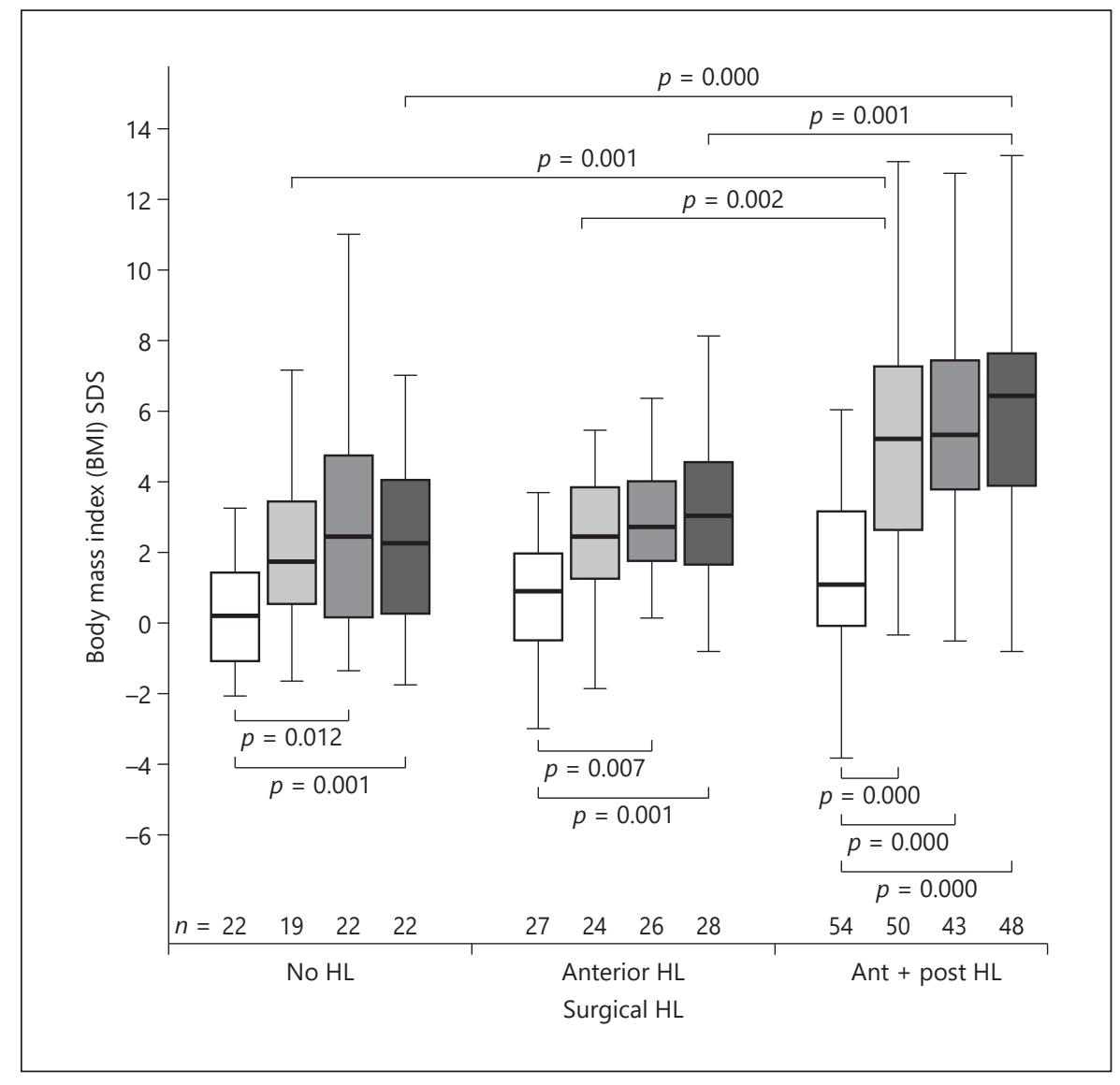

\section{Sequelae}

\section{Hypothalamic Syndrome}

Hypothalamic involvement of $\mathrm{CP}$ and/or lesions to hypothalamic structures due to surgical and/or radio-oncological interventions are associated with severe sequelae, mainly $\mathrm{HO}$, with a negative impact on the QoL of CP survivors [43-50]. 35\% of CP patients present with clinical manifestations associated with hypothalamic dysfunction, such as $\mathrm{HO}$, neuropsychological deficits, and disturbances of circadian rhythms at the time of diagnosis [50]. The incidence of hypothalamic dysfunction increases to $65-80 \%$ following radical surgical treatment [50].

Treatment of suprachiasmatic lesions with hypothalamic involvement is challenging and is associated with high morbidity [51]. HO is caused mainly by surgical lesions of posterior hypothalamic structures including the mammillary bodies [52, 53] (Fig. 3). Several reports have shown that the degree of $\mathrm{HO}$ is clearly associated with the grade of hypothalamic damage in CP patients $[53,54]$.

\section{Treatment Options for Hypothalamic Syndrome}

\section{Lifestyle and Dietary Interventions}

Due to disturbances in satiety regulation, central sympathetic output, and energy expenditure, CP patients often develop morbid $\mathrm{HO}$ that is mostly nonresponsive to conventional lifestyle modifications (diet and exercise) [55-59] (Table 1). Only 1 case report observed a clinical significant effect of a dietary intervention by a protein-sparing modified fasting program (PSMF) [60]; however, once it had been discontinued, weight gain occurred.

\section{Endocrine Substitution of Hypopituitarism}

Hypopituitarism should be treated by substitution of the deficient hormones according to existing guidelines [61]. Although safe with regard to the risk of CP recurrence, the beneficial effects of GH substitution on longterm body composition after $\mathrm{CP}$ are a topic for debate 
Table 2. Pharmacological treatment approaches for hypothalamic obesity

\begin{tabular}{|c|c|c|c|c|}
\hline $\begin{array}{l}\text { Pharmacolo- } \\
\text { gical agent }\end{array}$ & Mechanism of action & Patient cohorts & Outcomes & $\begin{array}{l}\text { First author, } \\
\text { [ref.], year }\end{array}$ \\
\hline \multirow[t]{3}{*}{$\begin{array}{l}\text { Dextro- } \\
\text { amphetamine }\end{array}$} & \multirow{3}{*}{$\begin{array}{l}\text { central stimulant, stimulation } \\
\text { of noradrenalin, dopamine } \\
\text { secretion, and dopamine } \\
\text { reuptake inhibition }\end{array}$} & 5 ped CP & $\begin{array}{l}\text { increase in physical activity, reduction in } \\
\text { continuous weight gain, stabilization of } \\
\text { BMI }\end{array}$ & $\begin{array}{l}\text { Mason [68], } \\
2002\end{array}$ \\
\hline & & $\begin{array}{l}9 \text { ped } \mathrm{CP} \\
2 \text { ped astrocytoma } \\
1 \text { ped glioma }\end{array}$ & $\begin{array}{l}\text { reduction in continuous weight gain and } \\
\text { stabilization of BMI in } 10 / 12 \mathrm{pts} \text {, improved } \\
\text { daytime sleepiness in } 11 / 12 \mathrm{pts}\end{array}$ & Ismail [69], 2006 \\
\hline & & $\begin{array}{l}4 \mathrm{CP}(3 \text { ped }) \\
1 \text { ped astrocytoma } \\
1 \text { ped ganglioglioma } \\
1 \text { ped meningitis }\end{array}$ & $\begin{array}{l}\text { reduction in continuous weight gain and } \\
\text { stabilization of BMI }\end{array}$ & $\begin{array}{l}\text { Denzer [70], } \\
2019\end{array}$ \\
\hline $\begin{array}{l}\text { Methyl- } \\
\text { phenidate }\end{array}$ & $\begin{array}{l}\text { central stimulant, dopamine } \\
\text { reuptake inhibition }\end{array}$ & 1 ped CP & beneficial against weight gain & Elfers [73], 2011 \\
\hline Octreotide & $\begin{array}{l}\text { somatostatin analog, reduced } \\
\beta \text { cell activation }\end{array}$ & $\begin{array}{l}13 \text { ped CP } \\
4 \text { ped astrocytoma } \\
1 \text { ped germinoma } \\
2 \text { ped ALL }\end{array}$ & $\begin{array}{l}\text { reduced insulin secretion, moderate to } \\
\text { no improvement in BMI, increased risk } \\
\text { of gall stone formation }\end{array}$ & $\begin{array}{l}\text { Lustig [108], } \\
2003\end{array}$ \\
\hline Diazoxide & $\begin{array}{l}\text { potassium channel activator, } \\
\text { inhibition of insulin secretion }\end{array}$ & 18 pts & no BMI change & $\begin{array}{l}\text { Brauner [74], } \\
2016\end{array}$ \\
\hline $\begin{array}{l}\text { Diazoxide }+ \\
\text { metformin }\end{array}$ & $\begin{array}{l}\text { reduced insulin secretion, } \\
\text { reduced hyperglycemia, } \\
\text { improved insulin sensitivity }\end{array}$ & 9 ped CP & $\begin{array}{l}\text { reduced weight gain, weight loss, } \\
\text { peripheral edema, emesis, elevated hepatic } \\
\text { enzymes }\end{array}$ & $\begin{array}{l}\text { Hamilton [75], } \\
2011\end{array}$ \\
\hline Exenatide & \multirow{2}{*}{$\begin{array}{l}\text { GLP-1 receptor agonists, } \\
\text { improved insulin sensitivity, } \\
\text { increased satiety, reduced } \\
\text { speed of gastric emptying }\end{array}$} & $\begin{array}{l}4 \text { ped } \mathrm{CP} \\
2 \text { adult } \mathrm{CP}\end{array}$ & $\begin{array}{l}\text { no significant weight loss in total cohort, } \\
\text { stable or decreased weight in responders } \\
(60 \%)\end{array}$ & $\begin{array}{l}\text { Lomenick [77], } \\
2016\end{array}$ \\
\hline Liraglutide & & 1 adult $\mathrm{CP}$ & $\begin{array}{l}\text { BMI reduction, i.e., from } 41.8 \text { to } 35.3 \text { after } \\
\text { an } 8 \text {-month intervention }\end{array}$ & $\begin{array}{l}\text { Zoicas [78], } \\
2013\end{array}$ \\
\hline $\begin{array}{l}\text { Oxytocin }+ \\
\text { naltraxone }\end{array}$ & $\begin{array}{l}\text { naltroxane (opiate antagonist) } \\
\text { decreases appetite and } \\
\text { potentiates anorexigenic } \\
\text { oxytocin effects }\end{array}$ & 1 ped CP & $\begin{array}{l}\text { improvement of hyperphagia and weight } \\
\text { loss }\end{array}$ & Hsu [86], 2018 \\
\hline $\begin{array}{l}\text { Supraphysiolo- } \\
\text { gic supplemen- } \\
\text { tation of T3 }\end{array}$ & $\begin{array}{l}\text { T3 increases energy } \\
\text { expenditure by induction of } \\
\text { thermogenesis }\end{array}$ & $\begin{array}{l}1 \text { adult pt (no } C P) \\
3 \text { ped pts (no CP) } \\
1 \text { ped } C P\end{array}$ & $\begin{array}{l}\text { weight reduction under } 3 \times 10 \mu \mathrm{g} 3 / \text { day } \\
\text { for } 11-27 \text { months } \\
\text { no weight reduction under } 3 \times 12.5 \mu \mathrm{g} \\
\text { T3/day for } 2 \text { months }\end{array}$ & $\begin{array}{l}\text { Fernandes } \\
\text { [109], 2002 } \\
\text { Van Santen } \\
{[110], 2015}\end{array}$ \\
\hline
\end{tabular}


Table 2 (continued)

\begin{tabular}{|c|c|c|c|c|}
\hline $\begin{array}{l}\text { Pharmacolo- } \\
\text { gical agent }\end{array}$ & Mechanism of action & Patient cohorts & Outcomes & $\begin{array}{l}\text { First author, } \\
\text { [ref.], year }\end{array}$ \\
\hline \multirow{3}{*}{$\begin{array}{l}\text { Substitution } \\
\text { with } \\
\text { recombinant } \\
\text { GH }\end{array}$} & \multirow{3}{*}{$\begin{array}{l}\text { beneficial effects of } \mathrm{GH} \text { on } \\
\text { body composition and } \\
\text { metabolism }\end{array}$} & 199 ped CP & $\begin{array}{l}\text { no } \mathrm{BMI} \text { reduction during } 3 \text { years of } \mathrm{GH} \\
\text { substitution }\end{array}$ & $\begin{array}{l}\text { Geffner [63], } \\
2004\end{array}$ \\
\hline & & 260 ped $\mathrm{CP}$ & $\begin{array}{l}\text { no BMI reduction during } 5 \text { years of } \mathrm{GH} \\
\text { substitution }\end{array}$ & Yuen [64], 2013 \\
\hline & & 79 ped CP & $\begin{array}{l}\text { beneficial long-term effect of GH on BMI } \\
\text { when substituted during childhood and } \\
\text { adulthood }\end{array}$ & $\begin{array}{l}\text { Boekhoff [62], } \\
2018\end{array}$ \\
\hline
\end{tabular}

GH, growth hormone; ped, pediatric; CP, craniopharyngioma; BMI, body mass index; GLP-1, glucagon-like receptor-1; pts, patients; RCT, randomized controlled trial; METAP2, methionine aminopeptidase 2; PPAR $\alpha$, peroxisome proliferator activated receptor $\alpha$; T3, tri-iodothyronine.

[62-65]. Glucocorticoid overreplacement should be avoided and levothyroxine should be substituted in a dose sufficient to achieve free T4 levels in the mid-to-upper half of the reference range [61].

\section{Pharmacological Treatment of HO}

Based on the observed reduction of epinephrine secretion and sympathoadrenal activation manifesting as an impaired endocrine response to hypoglycemia, pharmaceutical therapy with amphetamine derivatives has been analyzed [66-73]. Dextroamphetamine medication for 24 months, starting 10 months after surgery, stabilized $\mathrm{BMI}$, diminished continuous weight gain, and increased spontaneous physical activity level [68]. An improvement in daytime sleepiness was observed even after shorterterm dextroamphetamine medication [69]. Elfers and Roth [73] observed beneficial effects of methylphenidate on weight development after CP.

Several trials have analyzed the effects of antidiabetic agents on weight development in patients with $\mathrm{HO}$ [7482] (Table 2). Zoicas et al. [78] analyzed the effect of treatment with GLP-1 receptor agonist on weight development in 8 patients $(6 \mathrm{CP})$ with $\mathrm{HO}$. They reported a sustained weight loss and an improvement in cardiovascular and metabolic risk profiles.

Hamilton et al. [75] hypothesized that a combination therapy of diazoxide and metformin reduces insulin secretion and the risk of hyperglycemia. Insulin secretion is decreased by diazoxide binding to the KATP channel of $\beta$ cells. Metformin improves insulin sensitivity by decreasing hepatic gluconeogenesis. A combination therapy of diazoxide and metformin was evaluated in $9 \mathrm{CP}$ patients with HO. The synergism of lower insulin levels and enhanced insulin action led to an improved weight gain of $+1.2 \pm 5.9 \mathrm{~kg}$ versus the $+9.5 \pm 2.7 \mathrm{~kg}$ weight gain during the 6 months prior to therapy. High pretreatment insulin levels were associated with the most robust weight reduction [75]. The limitations of this trial were the small cohort size and the adverse events (1 patient withdrew due to the development of peripheral edema and another withdrew due to emesis and elevated hepatic enzymes).

Kalina et al. [76] treated 22 pediatric CP patients with a combination of fenofibrate and metformin. Fenofibrate is a peroxisome proliferator-activated receptor (PPAR) $\alpha$ agonist hypothesized to improve insulin sensitivity and reduce serum triglyceride concentration. Improved insulin resistance and lipid profiles were reported under metformin and fenofibrate medication. However, treatment with these agents did not result in an improvement in BMI.

CP patients with surgical damage limited to specific anterior hypothalamic structures were recently reported to present with reduced fasting oxytocin levels [83]. Furthermore, changes in oxytocin saliva concentrations before and after a standardized breakfast showed a significant correlation with BMI. CP patients with $\mathrm{HO}$ presented with impaired variation of oxytocin secretion due to their nutrition. The authors hypothesized that oxytocin medication might exert beneficial effects on neuropsychological deficiencies in $\mathrm{CP}$ patients with specific surgi- 
Table 3. Bariatric interventions for treatment of hypothalamic obesity

\begin{tabular}{|c|c|c|c|c|c|c|}
\hline \multirow[t]{2}{*}{ SG } & 3 ped & $\begin{array}{l}\text { mean BMI } 49.2 \\
(41.6-58.1)\end{array}$ & $\begin{array}{l}\text { mean BMI } 35.3 \\
(31.2-40.6)\end{array}$ & 2.0 years & $\begin{array}{l}\text { minor bleeding, folic acid } \\
\text { and vitamin } \mathrm{D} \text { deficiency }\end{array}$ & Trotta [96], 2017 \\
\hline & $2 \mathrm{pts}$ & $\begin{array}{l}\text { BMI } 51.0 \\
\text { BMI } 37.6\end{array}$ & $\begin{array}{l}\text { BMI } 41.0 \\
\text { BMI } 34.0\end{array}$ & 30 months & none reported & Gatta [93], 2013 \\
\hline \multirow[t]{4}{*}{ RYGB } & 1 ped & BMI 51.5 & BMI 39.0 & 9 months & none reported & Page-Wilson [90], 2012 \\
\hline & 1 ped & BMI 65.0 & BMI 43.0 & 4.0 years & $\begin{array}{l}\text { diarrhea, dumping } \\
\text { syndrome, psychological } \\
\text { deterioration }\end{array}$ & $\begin{array}{l}\text { Rottembourg [91], } \\
2009\end{array}$ \\
\hline & 3 pts & $\begin{array}{l}\text { BMI } 59.6 \\
\text { BMI } 42.3\end{array}$ & $\begin{array}{l}\text { mean weight loss } \\
20 \mathrm{~kg}\end{array}$ & 18 months & none & Bretault [94], 2016 \\
\hline & $5 \mathrm{pts}$ & $\begin{array}{l}\text { mean BMI 43.4, +5.2 } \\
\text { SD }\end{array}$ & $\begin{array}{l}\text { mean weight loss } \\
25 \%\end{array}$ & 24 months & none reported & Wijnen [88], 2017 \\
\hline $\begin{array}{l}\text { RYGB with } \\
\text { vagotomy }\end{array}$ & 1 ped & $\begin{array}{l}\text { weight } \\
223 \mathrm{~kg}\end{array}$ & weight loss $49 \mathrm{~kg}$ & 2.5 years & mild iron deficiency & Inge [89], 2007 \\
\hline \multirow{2}{*}{ Gastric bypass } & $2 \mathrm{pts}$ & $\begin{array}{l}\text { BMI } 43.7 \\
\text { BMI } 37.7\end{array}$ & $\begin{array}{l}\text { BMI } 37.5 \\
\text { BMI } 49.0\end{array}$ & $\begin{array}{l}48 \text { months } \\
64 \text { months }\end{array}$ & $\begin{array}{l}\text { septicemia, } \\
\text { esophagus ulceration }\end{array}$ & Gatta [93], 2013 \\
\hline & 1 ped & BMI 48.6 & weight loss & 36 months & none reported & Weismann [87], 2013 \\
\hline
\end{tabular}

LAGB, laparascopic adjustable gastric banding; SG, sleeve gastrectomy; RYGB, Roux-en-Y gastric bypass; ped, pediatric; CP, craniopharyngioma; BMI, body mass index; pts, patients.

cal lesions of the anterior hypothalamic structures. In a small pilot study on 11 CP patients, Hoffmann et al. [84] tested their hypothesis by means of a single nasal application of 24 IU of oxytocin. Before administration, all CP patients presented with detectable oxytocin saliva concentrations. The oxytocin was very well tolerated and resulted in an increase in oxytocin concentration in the sa- liva and urine. After administration, the CP patients with surgical hypothalamic lesions limited to the anterior hypothalamic areas presented an improvement with regard to emotional identification compared to $\mathrm{CP}$ patients with anterior and posterior hypothalamic lesions. Daubenbüchel et al. $[83,85]$ analyzed the association between oxytocin saliva concentration and eating behavior in $\mathrm{CP}$ 


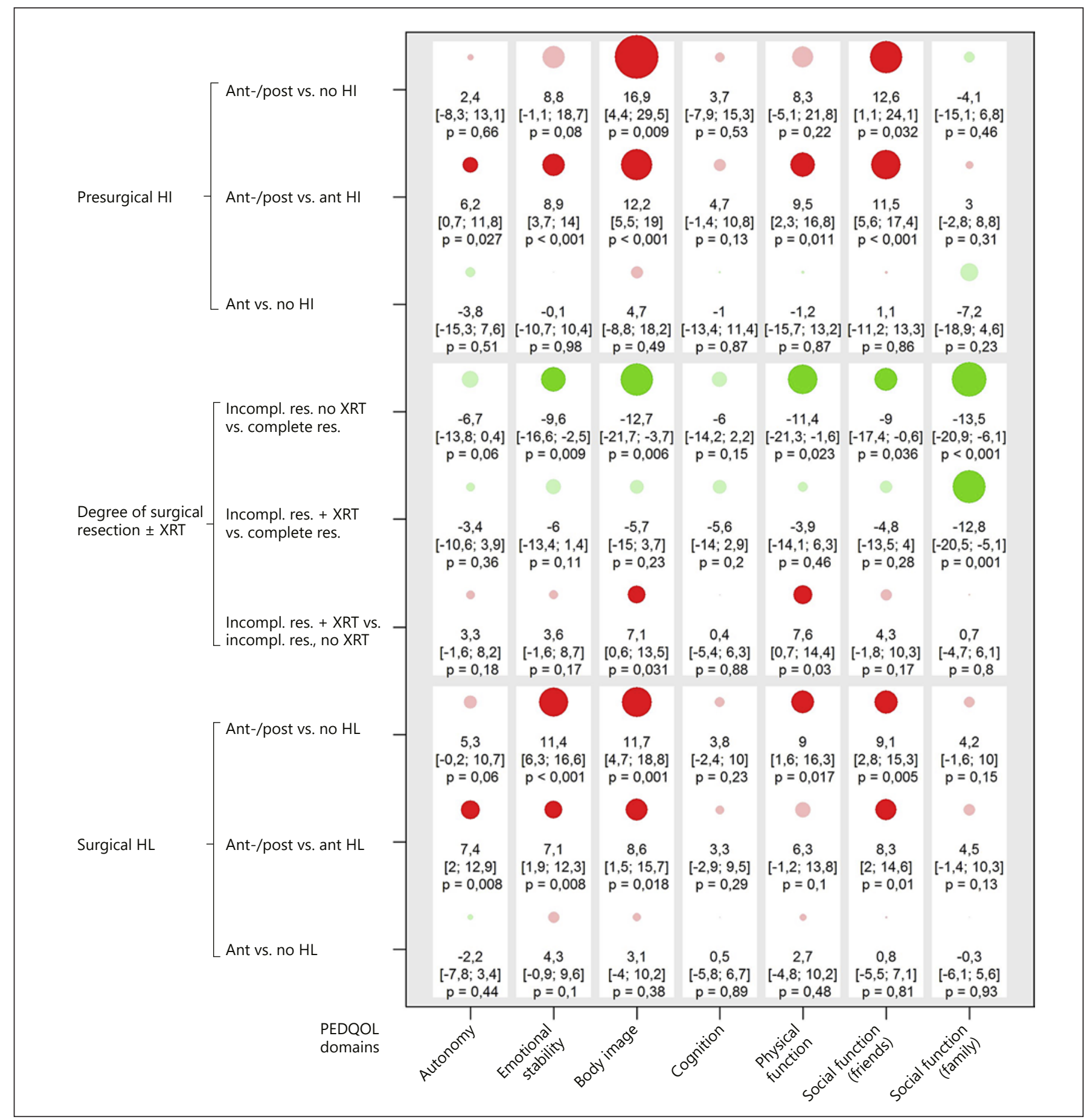

Fig. 4. Results of the linear mixed models for self-assessed quality of life (QoL) in craniopharyngioma patients recruited in the KRANIOPHARYNGEOM 2007 trial $(n=131)$. The PEDQOL score was modeled separately in each domain as a function of time, the factor in question, and the interaction between time and the factor in question. The results are displayed as differences of least-square estimates, with the associated 95\% confidence intervals and $p$ values, to describe the mean difference in PEDQOL scores between the 2 categories of each factor. The size of the circles is proportion- ate to the mean difference; circles representing positive and negative effects on QoL are colored green and red, respectively (opaque when $p \leq 0.05)$. A box corresponds to the results of a model. The higher the PEDQOL score, the lower the subjective QoL; a minus sign thus indicates a beneficial influence on QoL. HL, hypothalamic lesion; HI, hypothalamic involvement, Ant/ant, anterior; post, posterior; PEDQOL, Pediatric Quality of Life Questionnaire; res., resection; XRT, radiotherapy. Reproduced from [104] with permission from the Deutscher Ärzteverlag. 
patients and healthy controls. CP with anterior hypothalamic lesions and CP with anterior and posterior hypothalamic lesions presented with specific patterns of eating behavior. Reduced postprandial compared to fasting oxytocin saliva concentrations were associated with $\mathrm{HO}$ in $\mathrm{CP}$ patients and with adverse eating behavior and eating disorders in both CP patients and controls. Our current knowledge on the effects of long-term oxytocin medication for CP is based on a few case reports [86].

\section{Bariatric Treatment of HO}

Several reports on the effects of bariatric intervention for weight development in $\mathrm{HO}$ have been published with mixed results (Table 3) [87-96].

\section{Neuropsychological and Psychosocial Functioning}

The studies assessing physical and psychosocial functionality during long-term follow-up after CP report variable observations, ranging from reduced function in almost $50 \%$ to excellent function in the majority of patients [97-100]. A reduction in social and emotional functioning is the most frequently observed impairment, with $\mathrm{CP}$ patients rating their psychosocial status as worse than their physical health [97]. Other complaints are somatic symptoms such as reduced mobility and pain [97]. Behavioral studies observed frequent psychopathological symptoms, such as anxiety, depression, and withdrawal; recently, an increased risk of apathy in long-term survivors of childhood-onset CP was reported [101]. Difficulties in learning, emotional control, concerns about physical appearance and body image, and unsatisfactory peer relationships are frequent problems in children's daily functioning $[102,103]$.

\section{Quality of Life}

Systematic analysis of long-term health-related QoL has not yet been established. Eveslage et al. [104] recently reported on short-term QoL in patients recruited in the multinational KRANIOPHARYNGEOM 2007 trial [105]. CP patients treated with radical surgical strategies such as gross total resection resulting in surgical lesions of posterior hypothalamic areas presented with significantly lower self- and parent-assessed QoL during the short-term follow-up of 3 years after CP diagnosis (Fig. 4).

\section{Conclusion}

Although novel therapeutic approaches provide promising perspectives, it must be pointed out that currently no bariatric or pharmacological therapy for $\mathrm{HO}$ in $\mathrm{CP}$ patients has been proven to be effective based on randomized trials. Treatment approaches with combinations of pharmaceutical agents seem to be the most promising. Prevention of HO is recommended [1], with special regard to hypothalamus-sparing therapeutic approaches [32] that respect the integrity of essential nuclei located in posterior hypothalamic areas (Fig. 3) [36]. Any clinically significant improvement in the prognosis and outcome of CP patients will require the development of riskadapted, multidisciplinary neurosurgical and radio-oncological treatment strategies that provide medical as well as psychosocial support for these patients who suffer from what is a mostly chronic disease $[4,106]$.

\section{Acknowledgement}

I would like to thank my colleagues and the patients and their families for participating in trials on craniopharyngioma.

\section{Disclosure Statement}

The author received reimbursement of participation fees for scientific meetings and continuing medical education events from the following companies: Ferring, Lilly, Pfizer, Sandoz/Hexal, Novo Nordisk, Ipsen, and Merck Serono. He received reimbursement of travel expenses from Ipsen and lecture honoraria from Pfizer.

\section{Funding Sources}

A grant (DKS2014.13) was received from the German Childhood Cancer Foundation, Bonn, Germany.

\begin{tabular}{|c|c|}
\hline References & $\begin{array}{l}1 \text { Müller HL, Merchant TE, Puget S, Martinez- } \\
\text { Barbera JP. New outlook on the diagnosis, } \\
\text { treatment and follow-up of childhood-onset } \\
\text { craniopharyngioma. Nat Rev Endocrinol. } \\
2017 \text { May;13(5):299-312. } \\
2 \text { Müller HL. Childhood craniopharyngioma- } \\
\text { current concepts in diagnosis, therapy and } \\
\text { follow-up. Nat Rev Endocrinol. } 2010 \text { Nov; } \\
\text { 6(11):609-18. } \\
3 \text { Karavitaki N, Cudlip S, Adams CB, Wass JA. } \\
\text { Craniopharyngiomas. Endocr Rev. } 2006 \text { Jun; } \\
\text { 27(4):371-97. }\end{array}$ \\
\hline
\end{tabular}


4 Müller HL. Paediatrics: surgical strategy and quality of life in craniopharyngioma. Nat Rev Endocrinol. 2013 Aug;9(8):447-9.

5 Sekine S, Shibata T, Kokubu A, Morishita Y, Noguchi M, Nakanishi Y, et al. Craniopharyngiomas of adamantinomatous type harbor beta-catenin gene mutations. Am J Pathol. 2002 Dec;161(6):1997-2001.

6 Buslei R, Nolde M, Hofmann B, Meissner S, Eyupoglu IY, Siebzehnrübl F, et al. Common mutations of beta-catenin in adamantinomatous craniopharyngiomas but not in other tumours originating from the sellar region. Acta Neuropathol. 2005 Jun;109(6):589-97.

7 Brastianos PK, Taylor-Weiner A, Manley PE, Jones RT, Dias-Santagata D, Thorner AR, et al. Exome sequencing identifies BRAF mutations in papillary craniopharyngiomas. Nat Genet. 2014 Feb;46(2):161-5.

8 Hölsken A, Buchfelder M, Fahlbusch R, Blumcke I, Buslei R. Tumour cell migration in adamantinomatous craniopharyngiomas is promoted by activated Wnt-signalling. Acta Neuropathol. 2010 May;119(5):631-9.

9 Gaston-Massuet C, Andoniadou CL, Signore M, Jayakody SA, Charolidi N, Kyeyune R, et al. Increased Wingless (Wnt) signaling in pituitary progenitor/stem cells gives rise to pituitary tumors in mice and humans. Proc Natl Acad Sci USA. 2011 Jul;108(28):11482-7.

10 Goschzik T, Gessi M, Dreschmann V, Gebhardt U, Wang L, Yamaguchi S, et al. Genomic Alterations of Adamantinomatous and Papillary Craniopharyngioma. J Neuropathol Exp Neurol. 2017 Feb;76(2):126-34.

11 Hölsken A, Sill M, Merkle J, et al. Adamantinomatous and papillary craniopharyngiomas are characterized by distinct epigenomic as well as mutational and transcriptomic profiles. Acta Neuropathol Comm. 2016;4:20.

12 Haston S, Pozzi S, Carreno G, Manshaei S, Panousopoulos L, Gonzalez-Meljem JM, et al. MAPK pathway control of stem cell proliferation and differentiation in the embryonic pituitary provides insights into the pathogenesis of papillary craniopharyngioma. Development. 2017 Jun;144(12):2141-52.

13 Brastianos PK, Taylor-Weiner A, Manley PE, Jones RT, Dias-Santagata D, Thorner AR, et al. Exome sequencing identifies BRAF mutations in papillary craniopharyngiomas. Nat Genet. 2014 Feb;46(2):161-5.

14 Roque A, Odia Y. BRAF-V600E mutant papillary craniopharyngioma dramatically responds to combination BRAF and MEK inhibitors. CNS Oncol. 2017 Apr;6(2):95-9.

15 Himes BT, Ruff MW, Van Gompel JJ, et al. Recurrent papillary craniopharyngioma with BRAF V600E mutation treated with dabrafenib: case report. J Neurosurg. 2018 Apr;1: $1-5$.

16 Juratli TA, Jones PS, Wang N, Subramanian M, Aylwin SJ, Odia Y, et al. Targeted treatment of papillary craniopharyngiomas harboring BRAF V600E mutations. Cancer. 2019;125:17.
17 Hoffmann A, Boekhoff S, Gebhardt U, Sterkenburg AS, Daubenbüchel AM, Eveslage M, et al. History before diagnosis in childhood craniopharyngioma: associations with initial presentation and long-term prognosis. Eur J Endocrinol. 2015 Dec;173(6):853-62.

18 Müller HL, Emser A, Faldum A, Bruhnken G, Etavard-Gorris N, Gebhardt U, et al. Longitudinal study on growth and body mass index before and after diagnosis of childhood craniopharyngioma. J Clin Endocrinol Metab. 2004 Jul;89(7):3298-305.

19 Boekhoff S, Bison B, Eveslage M, Sowithayasakul P, Muller HL. Craniopharyngiomas presenting as incidentalomas: results of KRANIOPHARYNGEOM 2007. Pituitary. 2019 Oct;22(5):532-41.

20 Caldarelli M, Massimi L, Tamburrini G, Cappa M, Di Rocco C. Long-term results of the surgical treatment of craniopharyngioma: the experience at the Policlinico Gemelli, Catholic University, Rome. Childs Nerv Syst. 2005 Aug;21(8-9):747-57.

21 Müller HL. Childhood craniopharyngioma. Recent advances in diagnosis, treatment and follow-up. Horm Res. 2008;69(4):193-202.

22 Hoffman HJ, De Silva M, Humphreys RP, Drake JM, Smith ML, Blaser SI. Aggressive surgical management of craniopharyngiomas in children. J Neurosurg. 1992 Jan;76(1):4752.

23 Elliott RE, Jane JA Jr, Wisoff JH. Surgical management of craniopharyngiomas in children: meta-analysis and comparison of transcranial and transsphenoidal approaches. Neurosurgery. 2011 Sep;69(3):630-43.

24 Warmuth-Metz M, Gnekow AK, Muller H, Solymosi L. Differential diagnosis of suprasellar tumors in children. Klin Padiatr. 2004 Nov-Dec;216(6):323-30.

25 Müller HL. Craniopharyngioma - a childhood and adult disease with challenging characteristics. Front Endocrinol (Lausanne). 2012;3:80.

26 Hald JK, Eldevik OP, Skalpe IO. Craniopharyngioma identification by $\mathrm{CT}$ and MR imaging at 1.5 T. Acta Radiol. 1995 Mar;36(2):1427.

27 Famini P, Maya MM, Melmed S. Pituitary magnetic resonance imaging for sellar and parasellar masses: ten-year experience in 2598 patients. J Clin Endocrinol Metab. 2011 Jun; 96(6):1633-41.

28 Müller HL, Gebhardt U, Faldum A, Warmuth-Metz M, Pietsch T, Pohl F, et al. Xanthogranuloma, Rathke's cyst, and childhood craniopharyngioma: results of prospective multinational studies of children and adolescents with rare sellar malformations. J Clin Endocrinol Metab. 2012 Nov;97(11):393543.

29 de Vile CJ, Grant DB, Hayward RD, Kendall BE, Neville BG, Stanhope R. Obesity in childhood craniopharyngioma: relation to postoperative hypothalamic damage shown by magnetic resonance imaging. J Clin Endocrinol Metab. 1996 Jul;81(7):2734-7.
30 Terashima KH, Reich DS. Gadolinium deposition: practical guidelines in the face of uncertainty. Lancet Neurol. 2017 Jul;16(7):495-7.

31 Puget S, Garnett M, Wray A, et al. Pediatric craniopharyngiomas: classification and treatment according to the degree of hypothalamic involvement. J Neurosurg. 2007 Jan;106(1 Suppl):3-12.

32 Elowe-Gruau E, Beltrand J, Brauner R, Pinto G, Samara-Boustani D, Thalassinos C, et al. Childhood craniopharyngioma: hypothalamus-sparing surgery decreases the risk of obesity. J Clin Endocrinol Metab. 2013 Jun; 98(6):2376-82.

33 Fjalldal S, Follin C, Gabery S, Sundgren PC, Björkman-Burtscher IM, Lätt J, et al. Detailed assessment of hypothalamic damage in craniopharyngioma patients with obesity. Int J Obes. 2019 Mar;43(3):533-44.

34 Park SW, Jung HW, Lee YA, Shin CH, Yang SW, Cheon JE, et al. Tumor origin and growth pattern at diagnosis and surgical hypothalamic damage predict obesity in pediatric craniopharyngioma. J Neurooncol. 2013 Jul;113(3): 417-24.

35 Van Gompel JJ, Nippoldt TB, Higgins DM, Meyer FB. Magnetic resonance imaginggraded hypothalamic compression in surgically treated adult craniopharyngiomas determining postoperative obesity. Neurosurg Focus. 2010 Apr;28(4):E3.

36 Bogusz A, Boekhoff S, Warmuth-Metz M, Calaminus G, Eveslage M, Muller HL. Posterior hypothalamus-sparing surgery improves outcome after childhood craniopharyngioma. Endocr Connect. 2019;8:1.

37 Adeberg S, Harrabi SB, Bougatf N, Verma V, Windisch P, Bernhardt D, et al. Dosimetric Comparison of Proton Radiation Therapy, Volumetric Modulated Arc Therapy, and Three-Dimensional Conformal Radiotherapy Based on Intracranial Tumor Location. Cancers (Basel). 2018 Oct;10(11):401.

38 Merchant TE, Hua CH, Sabin ND, Ezell SE, Madey MA, Wu S, et al. Necrosis, vasculopathy, and neurological complications after proton therapy for childhood craniopharyngioma: results from a prospective trial and a photon cohort comparison. Int J Rad Biol Oncol Phys. 2016;96(2):S12-121.

39 Merchant T, Indelicato D, Hua C, Wu S, Conklin H. Comparison of academic scores after proton and photon therapy in children and young adults with craniopharyngioma. Pediatr Blood Cancer. 2017;64:e2677.

40 Kilday JP, Caldarelli M, Massimi L, Chen RH, Lee YY, Liang ML, et al. Intracystic interferon-alpha in pediatric craniopharyngioma patients: an international multicenter assessment on behalf of SIOPE and ISPN. Neurooncol. 2017 Oct;19(10):1398-407.

41 Cavalheiro S, Di Rocco C, Valenzuela S, Dastoli PA, Tamburrini G, Massimi L, et al. Craniopharyngiomas: intratumoral chemotherapy with interferon-alpha: a multicenter preliminary study with 60 cases. Neurosurg Focus. 2010 Apr;28(4):E12. 
42 Zhang S, Fang Y, Cai BW, Xu JG, You C. Intracystic bleomycin for cystic craniopharyngiomas in children. Cochrane Database Syst Rev. 2016 Jul;7:CD008890.

43 Müller HL. Craniopharyngioma. Endocr Rev. 2014 Jun;35(3):513-43.

44 Hoffmann A, Postma FP, Sterkenburg AS, Gebhardt U, Muller HL. Eating behavior, weight problems and eating disorders in 101 long-term survivors of childhood-onset craniopharyngioma. J Pediatr Endocrinol Metab. 2015 Jan;28(1-2):35-43.

45 Sterkenburg AS, Hoffmann A, Gebhardt U, Warmuth-Metz M, Daubenbuchel AM, Muller HL. Survival, hypothalamic obesity, and neuropsychological/psychosocial status after childhood-onset craniopharyngioma: newly reported long-term outcomes. Neurooncol. 2015 Jul;17(7):1029-38.

46 Daubenbüchel AM, Hoffmann A, Gebhardt U, Warmuth-Metz M, Sterkenburg AS, Müller HL. Hydrocephalus and hypothalamic involvement in pediatric patients with craniopharyngioma or cysts of Rathke's pouch: impact on long-term prognosis. Eur JEndocrinol. 2015 May;172(5):561-9.

47 Müller HL. Craniopharyngioma and hypothalamic injury: latest insights into consequent eating disorders and obesity. Curr Opin Endocrinol Diabetes Obes. 2016 Feb;23(1): 81-9.

48 Müller HL. MANAGEMENT OF ENDOCRINE DISEASE: Childhood-onset Craniopharyngioma: state of the art of care in 2018. Eur J Endocrinol. 2019;180:1.

49 Karavitaki N. Management of craniopharyngiomas. J Endocrinol Invest. 2014 Mar;37(3): $219-28$.

50 van Iersel L, Brokke KE, Adan RA, Bulthuis LC, van den Akker EL, van Santen HM. Pathophysiology and Individualized Treatment of Hypothalamic Obesity Following Craniopharyngioma and Other Suprasellar Tumors: A Systematic Review. Endocr Rev. 2019 Feb;40(1):193-235.

51 Müller HL. Hypothalamic involvement in craniopharyngioma-Implications for surgi$\mathrm{cal}$, radiooncological, and molecularly targeted treatment strategies. Pediatr Blood Cancer. 2018 May;65(5):e26936.

52 Müller HL. Consequences of craniopharyngioma surgery in children. J Clin Endocrinol Metab. 2011 Jul;96(7):1981-91.

53 Müller HL, Gebhardt U, Teske C, Faldum A, Zwiener I, Warmuth-Metz M, et al. Post-operative hypothalamic lesions and obesity in childhood craniopharyngioma: results of the multinational prospective trial KRANIOPHARYNGEOM 2000 after 3-year follow-up. Eur J Endocrinol. 2011 Jul;165(1):17-24.

54 Holmer H, Ekman B, Bjork J, Nordstöm CH, Popovic V, Siversson AB, et al. Hypothalamic involvement predicts cardiovascular risk in adults with childhood onset craniopharyngioma on long-term GH therapy. Eur J Endocrinol. 2009 Nov;161(5):671-9.
55 Rakhshani N, Jeffery AS, Schulte F, Barrera M, Atenafu EG, Hamilton JK. Evaluation of a comprehensive care clinic model for children with brain tumor and risk for hypothalamic obesity. Obesity (Silver Spring). 2010 Sep; 18(9):1768-74.

56 Sterkenburg AS, Hoffmann A, Gebhardt U, Waldeck E, Springer S, Muller HL. [Childhood craniopharyngioma with hypothalamic obesity - no long-term weight reduction due to rehabilitation programs]. Klin Padiatr. 2014 Nov;226(6-7):344-50.

57 Meijneke RW, Schouten-van Meeteren AY, de Boer NY, van Zundert S, van Trotsenburg PA, Stoelinga F, et al. Hypothalamic obesity after treatment for craniopharyngioma: the importance of the home environment. J Pediatr Endocrinol Metab. 2015 Jan;28(1-2):5963.

58 Skorzewska A, Lal S, Waserman J, Guyda H. Abnormal food-seeking behavior after surgery for craniopharyngioma. Neuropsychobiology. 1989;21(1):17-20.

59 Steele CA, Cuthbertson DJ, MacFarlane IA, Javadpour M, Das KS, Gilkes C, et al. Hypothalamic obesity: prevalence, associations and longitudinal trends in weight in a specialist adult neuroendocrine clinic. Eur J Endocrinol. 2013 Apr;168(4):501-7.

60 Lee YJ, Backeljauw PF, Kelly PD, Verdi PD, Redmond GP. Successful weight loss with protein-sparing modified fast in a morbidly obese boy with panhypopituitarism, diabetes insipidus, and defective thirst regulation. Clin Pediatr. 1992 Apr;31(4):234-6.

61 Fleseriu M, Hashim IA, Karavitaki N, Melmed S, Murad MH, Salvatori R, et al. Hormonal Replacement in Hypopituitarism in Adults: An Endocrine Society Clinical Practice Guideline. J Clin Endocrinol Metab. 2016 Nov;101(11):3888-921.

62 Boekhoff S, Bogusz A, Sterkenburg AS, Eveslage M, Muller HL. Long-term Effects of Growth Hormone Replacement Therapy in Childhood-onset Craniopharyngioma: Results of the German Craniopharyngioma Registry (HIT-Endo). Eur J Endocrinol. 2018 Oct; 179(5):331-41.

63 Geffner M, Lundberg M, KoltowskaHaggstrom M, Abs R, Verhelst J, Erfurth EM, et al. Changes in height, weight, and body mass index in children with craniopharyngioma after three years of growth hormone therapy: analysis of KIGS (Pfizer International Growth Database). J Clin Endocrinol Metab. 2004 Nov;89(11):5435-40.

64 Yuen KC, Koltowska-Haggstrom M, Cook DM, Fox JL, Jönsson PJ, Geffner ME, et al. Clinical characteristics and effects of GH replacement therapy in adults with childhoodonset craniopharyngioma compared with those in adults with other causes of childhood-onset hypothalamic-pituitary dysfunction. Eur J Endocrinol. 2013 Oct;169(4):5119.
65 Heinks K, Boekhoff S, Hoffmann A, Warmuth-Metz M, Eveslage M, Peng J, et al. Quality of life and growth after childhood craniopharyngioma: results of the multinational trial KRANIOPHARYNGEOM 2007. Endocrine. 2018 Feb;59(2):364-72.

66 Schöfl C, Schleth A, Berger D, Terkamp C, von zur Muhlen A, Brabant G. Sympathoadrenal counterregulation in patients with hypothalamic craniopharyngioma. J Clin Endocrinol Metab. 2002 Feb;87(2):624-9.

67 Coutant R, Maurey H, Rouleau S, Mathieu E, Mercier P, Limal JM, et al. Defect in epinephrine production in children with craniopharyngioma: functional or organic origin? J Clin Endocrinol Metab. 2003 Dec;88(12):5969-75.

68 Mason PW, Krawiecki N, Meacham LR. The use of dextroamphetamine to treat obesity and hyperphagia in children treated for craniopharyngioma. Arch Pediatr Adolesc Med. 2002 Sep;156(9):887-92.

69 Ismail D, O'Connell MA, Zacharin MR. Dexamphetamine use for management of obesity and hypersomnolence following hypothalamic injury. J Pediatr Endocrinol Metab. 2006 Feb;19(2):129-34.

70 Denzer C, Denzer F, Lennerz BS, Vollbach H, Lustig RH, Wabitsch M. Treatment of Hypothalamic Obesity with Dextroamphetamine: A Case Series. Obes Facts. 2019;12(1):91-102.

71 Sadatomo T, Sakoda K, Yamanaka M, Kutsuna M, Kurisu K. Mazindol administration improved hyperphagia after surgery for craniopharyngioma-case report. Neurol Med Chir (Tokyo). 2001 Apr;41(4):210-2.

72 Greenway FL, Bray GA. Treatment of hypothalamic obesity with caffeine and ephedrine. Endocr Pract. 2008 Sep;14(6):697-703.

73 Elfers CT, Roth CL. Effects of methylphenidate on weight gain and food intake in hypothalamic obesity. Front Endocrinol (Lausanne). 2011;2:78.

74 Brauner R, Serreau R, Souberbielle JC, Pouillot M, Grouazel S, Recasens C, et al. Diazoxide in Children with Obesity After Hypothalamic-Pituitary Lesions: A Randomized, PlaceboControlled Trial. J Clin Endocrinol Metab. 2016 Dec;101(12):4825-33.

75 Hamilton JK, Conwell LS, Syme C, Ahmet A, Jeffery A, Daneman D. Hypothalamic Obesity following Craniopharyngioma Surgery: Results of a Pilot Trial of Combined Diazoxide and Metformin Therapy. Int J Pediatr Endocrinol. 2011;2011(1):417949.

76 Kalina MA, Wilczek M, Kalina-Faska B, Skala-Zamorowska E, Mandera M, Malecka Tendera E. Carbohydrate-lipid profile and use of metformin with micronized fenofibrate in reducing metabolic consequences of craniopharyngioma treatment in children: single institution experience. J Pediatr Endocrinol Metab. 2015 Jan;28(1-2):45-51.

77 Lomenick JP, Buchowski MS, Shoemaker AH. A 52-week pilot study of the effects of exenatide on body weight in patients with hypothalamic obesity. Obesity (Silver Spring). 2016 Jun;24(6):1222-5. 
78 Zoicas F, Droste M, Mayr B, Buchfelder M, Schofl C. GLP-1 analogues as a new treatment option for hypothalamic obesity in adults: report of nine cases. Eur J Endocrinol. 2013 May;168(5):699-706.

79 Simmons JH, Shoemaker AH, Roth CL. Treatment with glucagon-like Peptide-1 agonist exendin-4 in a patient with hypothalamic obesity secondary to intracranial tumor. Horm Res Paediatr. 2012;78(1):54-8.

80 Thondam SK, Cuthbertson DJ, Aditya BS, Macfarlane IA, Wilding JP, Daousi C. A glucagon-like peptide-1 (GLP-1) receptor agonist in the treatment for hypothalamic obesity complicated by type 2 diabetes mellitus. Clin Endocrinol (Oxf). 2012 Oct;77(4):635-7.

81 Castro-Dufourny I, Carrasco R, Pascual JM. Hypothalamic obesity after craniopharyngioma surgery: treatment with a long acting glucagon like peptide 1 derivated. Endocrinol Diabetes Nutr. 2017 Mar;64(3):182-4.

82 Igaki N, Tanaka M, Goto T. Markedly improved glycemic control and enhanced insulin sensitivity in a patient with type 2 diabetes complicated by a suprasellar tumor treated with pioglitazone and metformin. Intern Med. 2005 Aug;44(8):832-7.

83 Daubenbüchel AM, Hoffmann A, Eveslage M, Özyurt J, Lohle K, Reichel J, et al. Oxytocin in survivors of childhood-onset craniopharyngioma. Endocrine. 2016 Nov;54(2):52431.

84 Hoffmann A, Ozyurt J, Lohle K, Reichel J, Thiel CM, Muller HL. First experiences with neuropsychological effects of oxytocin administration in childhood-onset craniopharyngioma. Endocrine. 2017 Apr;56(1):17585

85 Daubenbüchel AM, Ozyurt J, Boekhoff S, Warmuth-Metz M, Eveslage M, Müller HL. Eating behaviour and oxytocin in patients with childhood-onset craniopharyngioma and different grades of hypothalamic involvement. Pediatr Obes. 2019;14:e12527.

86 Hsu EA, Miller JL, Perez FA, Roth CL. Oxytocin and Naltrexone Successfully Treat Hypothalamic Obesity in a Boy Post-Craniopharyngioma Resection. J Clin Endocrinol Metab. 2018 Feb;103(2):370-5.

87 Weismann D, Pelka T, Bender G, Jurowich C, Fassnacht M, Thalheimer A, et al. Bariatric surgery for morbid obesity in craniopharyngioma. Clin Endocrinol (Oxf). 2013 Mar; 78(3):385-90

88 Wijnen M, Olsson DS, van den HeuvelEibrink MM, Wallenius V, Janssen J A MJ Delhanty PJ, et al. Efficacy and safety of bariatric surgery for craniopharyngioma-related hypothalamic obesity: a matched case-control study with 2 years of follow-up. Int J Obes. 2017 Feb;41(2):210-6.
89 Inge TH, Pfluger P, Zeller M, Rose SR, Burget L, Sundararajan S, et al. Gastric bypass surgery for treatment of hypothalamic obesity after craniopharyngioma therapy. Nat Clin Pract Endocrinol Metab. 2007 Aug;3(8):606-

90 Page-Wilson G, Wardlaw SL, Khandji AG, Korner J. Hypothalamic obesity in patients with craniopharyngioma: treatment approaches and the emerging role of gastric bypass surgery. Pituitary. 2012 Mar;15(1):8492.

91 Rottembourg D, O'Gorman CS, Urbach S, Garneau PY, Langer JC, Van Vliet G, et al. Outcome after bariatric surgery in two adolescents with hypothalamic obesity following treatment of craniopharyngioma. J Pediatr Endocrinol Metab. 2009 Sep;22(9):867-72.

92 Müller HL, Gebhardt U, Maroske J, Hanisch E. Long-term follow-up of morbidly obese patients with childhood craniopharyngioma after laparoscopic adjustable gastric banding (LAGB). Klin Padiatr. 2011 Nov;223(6):3723

93 Gatta B, Nunes ML, Bailacq-Auder C, Etchechoury L, Collet D, Tabarin A. Is bariatric surgery really inefficient in hypothalamic obesity? Clin Endocrinol (Oxf). 2013 Apr; 78(4):636-8.

94 Bretault M, Laroche S, Lacorte JM, Barsamian C, Polak M, Raffin-Sanson ML, et al. Postprandial GLP-1 Secretion After Bariatric Surgery in Three Cases of Severe Obesity Related to Craniopharyngiomas. Obes Surg. 2016 May;26(5):1133-7.

95 Wolf P, Winhofer Y, Smajis S, Kruschitz R, Schindler K, Gessl A, et al. Hormone Substitution after Gastric Bypass Surgery in Patients with Hypopituitarism Secondary to Craniopharyngioma. Endocr Pract. 2016 May;22(5): 595-601.

96 Trotta M, Da Broi J, Salerno A, Testa RM, Marinari GM. Sleeve gastrectomy leads to easy management of hormone replacement therapy and good weight loss in patients treated for craniopharyngioma. Updates Surg. 2017 Mar;69(1):95-9.

97 Poretti A, Grotzer MA, Ribi K, Schonle E, Boltshauser E. Outcome of craniopharyngioma in children: long-term complications and quality of life. Dev Med Child Neurol. 2004 Apr;46(4):220-9.

98 Müller HL, Faldum A, Etavard-Gorris N, et al. Functional capacity, obesity and hypothalamic involvement: cross-sectional study on 212 patients with childhood craniopharyngioma. Klin Padiatr. 2003 Nov-Dec;215(6):310-4.

99 Müller HL, Bruhnken G, Emser A, Faldum A, Etavard-Gorris N, Gebhardt U, et al. Longitudinal study on quality of life in 102 survivors of childhood craniopharyngioma. Childs Nerv Syst. 2005 Nov;21(11):975-80.
100 Müller HL, Gebhardt U, Faldum A, Emser A, Etavard-Gorris N, Kolb R, et al. Functional capacity and body mass index in patients with sellar masses-cross-sectional study on 403 patients diagnosed during childhood and adolescence. Childs Nerv Syst. 2005 Jul;21(7):539-45.

101 Mehren A, Ozyurt J, Zu Klampen P, Boekhoff S, Thiel CM, Muller HL. Self- and informant-rated apathy in patients with childhood-onset craniopharyngioma. J Neurooncol. 2018 Oct;140(1):27-35.

102 Ondruch A, Maryniak A, Kropiwnicki T, Roszkowski M, Daszkiewicz P. Cognitive and social functioning in children and adolescents after the removal of craniopharyngioma. Childs Nerv Syst. 2011;27(3):391-7.

103 Crom D, Smith D, Xiong Z, Onar A, Hudson MM, Merchant TE, et al. Health Status in Long-Term Survivors of Pediatric Craniopharyngiomas. J Neurosci Nurs. 2010; 42(6):323-8.

104 Eveslage M, Calaminus G, Warmuth-Metz $\mathrm{M}$, et al. The Postoperative Quality of Life in Children and Adolescents with Craniopharyngioma. Dtsch Arztebl Int. 2019 May; 116(18):321-8

105 Hoffmann A, Warmth-Metz M, Gebhardt U, Pietsch T, Pohl F, Kortmann RD, et al. Childhood craniopharyngioma - changes of treatment strategies in the trials KRANIOPHARYNGEOM 2000/2007. Klin Padiatr. 2014 May;226(3):161-8

106 Müller HL. Diagnostics, treatment, and follow-up in craniopharyngioma. Front Endocrinol (Lausanne). 2011;2:70.

107 Rolland-Cachera MF, Cole TJ, Sempe M, Tichet J, Rossignol C, Charraud A. Body Mass Index variations: centiles from birth to 87 years. Eur J Clin Nutr. 1991 Jan;45(1): 13-21.

108 Lustig RH, Hinds PS, Ringwald-Smith K, Christensen RK, Kaste SC, Schreiber RE, et al. Octreotide therapy of pediatric hypothalamic obesity: a double-blind, placebo-controlled trial. J Clin Endocrinol Metab. 2003 Jun;88(6):2586-92.

109 Fernandes JK, Klein MJ, Ater JL, Kuttesch JF, Vassilopoulou-Sellin R. Triiodothyronine supplementation for hypothalamic obesity. Metabolism. 2002 Nov;51(11): 1381-3.

110 van Santen HM, Schouten-Meeteren AY, Serlie M, Meijneke RW, van Trotsenburg AS, Verberne H, et al. Effects of T3 treatment on brown adipose tissue and energy expenditure in a patient with craniopharyngioma and hypothalamic obesity. J Pediatr Endocrinol Metab. 2015 Jan;28(1-2): $53-7$. 